\title{
Non-Native English Teachers' Beliefs on Grammar Instruction
}

\author{
Okan Önalan ${ }^{1}$ \\ ${ }^{1}$ National Defense University, Turkey \\ Correspondence: Okan Önalan, National Defense University, Turkey. E-mail: okanonalan@gmail.com
}

$\begin{array}{lc}\text { Received: January 4, } 2018 & \text { Accepted: April 2, } 2018 \quad \text { Online Published: April 4, } 2018 \\ \text { doi: 10.5539/elt.v11n5p1 } & \text { URL: http://doi.org/10.5539/elt.v11n5p1 }\end{array}$

\begin{abstract}
Research on teacher cognition, which mainly focuses on identifying what teachers think, know and believe, is essential to understanding teachers' cognitive framework as it relates to the instructional choices they make. The aim of this study is to find out the beliefs of non-native speaker teachers of English on grammar instruction and to explain how those reported beliefs are influenced by particular demographic factors. 75 non-native speaker teachers of English participated in the study. Data was collected by a 5-Likert type questionnaire with 15 items that addressed a range of key issues in grammar instruction, particularly direct (explicit) or indirect (integrated) grammar instruction. The study has provided a number of valuable insights, particularly in relation to teachers' beliefs about grammar instruction. The representation of grammar instruction that arises from participant teachers' responses in this study is one characterized by systematic explicit grammar teaching with regular opportunities for grammar practice, not in isolation but in relation to skills-oriented work. Moreover, teachers with higher English proficiency levels and higher degrees (master's/doctorate) showed stronger belief towards teaching grammar indirectly. Teachers of adult learners showed a higher tendency towards direct grammar teaching. Non-native speaker teachers preferred to use more indirect grammar instruction as they progressed academically and proficiency-wise, but they implemented more direct grammar teaching as the ages and level of their students increased.
\end{abstract}

Keywords: EFL teachers, non-native teachers, beliefs, grammar instruction, direct grammar, indirect grammar, teacher cognition

\section{Introduction}

Teaching is a profession built fundamentally around decision making processes. Teachers have to make all kinds of decisions before, during and after teaching. These may vary from a slight alteration in an activity on the spot to avoiding a certain subject brought up by the class. Since decision making skills take knowledge and experience to develop, teachers should have a framework in order to make educated choices. There is evidence that teachers base instructional decisions on their own practical theories shaped by a range of interacting factors, both inside and beyond the classroom (e.g. Bailey, 1996; Burns, 1996; Borg, 1999). Therefore, research on teacher cognition, which mainly focuses on identifying what teachers think, know and believe, is essential to understanding teachers' cognitive framework as it relates to the instructional choices they make.

Findings in cognitive psychology draw attention to multifaceted relationships between what people do and what they know and believe. Therefore, educational researchers have become more aware of the fact that teachers' mental framework plays a significant role in their instructional choices. Consequently, researchers pose the questions such as 'what do teachers think?', 'what decisions do they make?' and 'why do they make such decisions?'. This emphasis on cognition is a major change in that teaching is no longer seen only in terms of behaviors, but rather as set of thoughtful behaviors (Borg, 2003a). Correspondingly, teachers are not perceived as mechanical individuals who implement external prescriptions, but as active, thinking and questioning decision-makers.

Although the interest in teacher cognition research had eventually an effect on the field of L2 language education, it was not until the mid-90s that it was recognized as an important area of research. Freeman and Richards (1996) conducted one of the early studies that underlined the value of understanding language teaching by examining the mental side of teachers' work. Similarly, Woods (1996) published a lengthy study of teacher cognition in the same year and it brought the term to the closer attention of L2 researchers. From then on, there has been a marked increase in the volume of research on language teacher cognition. For instance, the most researched area 
has been L2 grammar teaching and this work has made great contribution to our understandings of how teachers teach grammar and of the cognitive framework behind their instructional practices.

\section{Literature Review}

Considering the complexity of factors and variables in grammar instruction (e.g. how grammar is and should be taught: implicitly-explicitly, inductively-deductively, integratedly-separately, whether or not knowledge of grammatical terminology enhances learning, whether grammar work is best handled through L1 or L2, etc), researchers have looked for exact and commonly applicable answers to questions teachers encounter in grammar teaching (Ellis, 2006). To address such issues on the learning and teaching of L2 grammar, a teacher cognition perspective has more recently been applied to the study of L2 grammar teaching. In his comprehensive literature review, Borg (2003b) divides teacher cognition studies on grammar teaching under three categories in terms of their focus of inquiry: (i) teachers' knowledge of grammar; (ii) teachers' beliefs about grammar teaching; and (iii) practices and cognitions in teaching grammar. Results of these studies reveal that teachers do indeed have a set of complex belief systems about the teaching of grammar, and that these are sometimes not reflected in their classroom practices for various complicated reasons.

Apparently, teacher cognition research on grammar instruction has shown that what teachers do in the classroom may not necessarily reflect their beliefs about how grammar should be taught (Basturkmen, Loewen, \& Ellis, 2004). Evidence suggests that how teachers handle grammar is strongly influenced by their views about language learning, their beliefs about their students' needs and wants, and other contextual factors such as time (Farrell \& Lim, 2005). For instance, teachers' own knowledge about grammar plays a significant role in the instructional decisions they make (Andrews, 2007). More interestingly, it is not only teachers' actual knowledge of grammar that affects their teaching, but also how confident they feel about this knowledge. Borg's studies on both native speaker (NS) and non-native speaker (NNS) teachers suggest that less confident teachers tend to decrease the amount of explicit grammar work in the classroom, which in turn leads to an avoidance of grammar teaching in language lessons (Borg 1998a, 1998b, 1999, 2001, 2005).

Now that NNS teachers are increasingly prevalent in language teaching, particularly teaching English both in ESL (English as a Second Language) and EFL (English as a Foreign Language) contexts worldwide (e.g. Braine 1999, Llurda 2005, and Mahboob 2010 for theoretical and empirical overview), understanding their specific contributions as well as their cognition has become more significant than before. However, there is not as much empirical research on non-native speaker teacher cognition with reference to grammar teaching as on native speaker teachers. More to the point, the studies on NNS teachers usually follow a narrow perspective, involving teachers from one single country or region (e.g. Hayes, 2005 - Sri Lanka; Pahissa \& Tragant 2009 - Catalonia). Consequently, given such insights and the current prominence of grammar teaching in debates about English language teaching worldwide, further qualitative research on NNS teachers in an international context is needed in order to develop closer understanding of what they think, believe and do as well as of the cognitive framework underlining their pedagogical decisions in relation to grammar. This study has been conducted upon this necessity.

\section{Method}

\subsection{Research Questions}

Informed by the literature on teacher cognition on grammar teaching and the NNS teacher stance in L2 teaching field discussed above, this study addressed the following research questions:

1) What beliefs about grammar instruction are reported by non-native speaker (NNS) teachers of English?

2) How do the reported beliefs about grammar teaching by NNS teachers relate to (a) their qualifications; (b) their students' age; (c) the proficiency level of students they teach; and (d) their English proficiency level.

\subsection{Context}

This study was conducted in a language institute in San Antonio, Texas, USA. The language institute involved three academic training sections: General English, Specialized English and Instructor Development. The Instructor Development sector, whose students are the participants of this study, offered occupational development courses for non-native speaker teachers of English and hosted teachers of English from all around the world. The Instructor Development module was a 16-week in-service training course that highlighted communicative language teaching principles. The textbooks used for the module were "Principles of Language Learning and Teaching" (Brown, 2000) and "Teaching by Principles" (Brown, 2007). The module followed a discussion-reflection based approach, supported by out-of-class article reading, individual-collaborative projects, and micro-teaching sessions. A typical class day consisted of six hours of instruction; some of which may be 
spent in a computer-based language laboratory. All teacher trainees had access to a learning center, which had a variety of multimedia software and included a library. The program also involved extra-curricular activities such as field trips to libraries, to other schools and to touristic places of the region. Both the institution and the four instructors who offered the instructor development courses enjoyed a good academic reputation in the region.

\subsection{Participants}

The participants' demographic information presented here has been obtained from the first part of the survey. After the official permission was granted from the language institution to conduct a survey-based study at the Instructor Development sector, printed surveys with informed consent documents were delivered to 96 trainees. Participants were given four days to fill in the surveys and to return them. Consequently, 75 NNS teachers of English from 29 different countries agreed to participate in the study.

Of the 75 participants, 46 (61.3\%) were male and 29 (38.7\%) were female teachers. In order to obtain an overall idea of participant teachers' occupational framework, the survey included questions that aimed at eliciting participants' educational qualifications. 39 (52\%) of them had a bachelor's degree in ELT, and 36 (48\%) teachers had earned either their master's or doctorate degrees in the field. As for total years spent in teaching, $15(20 \%)$ teachers were in the first 4 years of their career, $23(30.7 \%)$ of them had 5 to 9 years of experience, $20(26.7 \%)$ participants had been teaching for 10 to 14 years, and finally $17(22.7 \%)$ of them were highly experienced with 15 years and above. These percentages show that a significant number of participants engaged in advanced academic studies and had more than 10 years of experience in the field, which may suggest that the participants had a high level of occupational expertise. Information on participants' qualifications (Table 1) is presented below.

Table 1. Participants' qualification

\begin{tabular}{lll}
\hline & $\mathrm{n}$ & $\%$ \\
\hline Bachelor's Degree (BA) & 39 & 52 \\
Master's (MA) / Doctorate (PhD) & 36 & 48 \\
TOTAL & 75 & 100,0 \\
\hline
\end{tabular}

Additionally, the participants were asked to specify the context in which they taught English. This piece of information was collected not only to learn about the age range of students the participants dealt with, but also to account for the proficiency level they had to address. $8(10.7 \%)$ teachers taught English to high school students, $19(25.3 \%)$ of them had university level students, and $48(64 \%)$ teachers offered English lessons to adult learners who were 24 of age and above (Table 2). As to the proficiency level of their students, 33 (44\%) participants taught elementary level, 21 (28\%) of them had intermediate level students, and 21 (28\%) of them offered English lessons to advanced level students (Table 3 ).

Table 2. Age range of participants' students

\begin{tabular}{llll}
\hline Participants' Students & $\mathrm{n}$ & $\%$ \\
\hline High School & Teaching Students Aged 15-18 & 8 & 10,7 \\
University / Academy & Teaching Students Aged 19-23 & 19 & 25,3 \\
Graduate / In-service & Teaching Students Aged 24 and above & 48 & 64 \\
TOTAL & & 75 & 100,0 \\
\hline
\end{tabular}

Table 3. Proficiency level of participants' students

\begin{tabular}{lll}
\hline & $\mathrm{n}$ & $\%$ \\
\hline Elementary & 33 & 44 \\
Intermediate & 21 & 28 \\
Advanced & 21 & 28 \\
TOTAL & 75 & 100,0 \\
\hline
\end{tabular}


The participant NNS teachers' proficiency level in English language was another factor correlated to their stated beliefs as a part of the second research question. In order to account for this information, they were asked to point out a proficiency score in English language; in this case their ECL (English Comprehension Level) scores. The ECL test is one of the instruments used for measuring the English language reading, vocabulary, grammar and listening proficiency of international participants in certain US-sponsored courses. The ECL may also be used as a criterion in the recruitment of US military personnel who are not native speakers of English, or in the determination of their eligibility for commissioning, attending specific courses or holding certain jobs. The ECL is administered in approximately 120 overseas sites, and over 100 sites in the U.S. in one of two versions: paper/pencil or online computer-delivered. These tests consist of 100 multiple-choice items, take about 75 minutes to administer, and are scored on a scale of 0 to 100 .

In many cases, it is hard to find a common proficiency test that all participant teachers have taken (e.g. TOEFL, IELTS, etc) and the number of studies in literature that have reported teachers command of English over a standardized proficiency test score is rather limited. Providentially, all trainees in the Instructor Development sector took the ECL exam as a prerequisite before the module started. A computer-adaptive (CAT) version of the ECL was given to all trainees by the administration in order to group them into heterogeneous classes for practical and methodological purposes. The CAT ECL is essentially an individualized test, reducing the average test time to about 17 minutes. Like the other versions, CAT ECL scores are reported on a scale of 0 to 100 . Although CAT ECL did not assess writing and speaking skills, participants' ECL scores were readily acknowledged as an indicator of their English proficiency considering the difficulty of determining participants' proficiency level by a common test in any study. Table 4 shows the CAT ECL scores of the participants.

Table 4. Participants' proficiency in English

\begin{tabular}{lll}
\hline Participants' CAT ECL Scores & $\mathrm{n}$ & $\%$ \\
\hline $80-90$ & 20 & 26.7 \\
$91-100$ & 55 & 73.3 \\
TOTAL & 75 & 100.0 \\
\hline
\end{tabular}

\subsection{Data Collection}

The survey used in this study consisted of two parts. Data obtained from each part accounted for one or more research questions. Part 1 elicited participants' demographic and background information. The data obtained from this part was used to provide information about the composition of the sample group as well as the key participant variables of the second research question. Part 2 was a questionnaire taken from Burg and Burns (2008). The questionnaire had 15 items that addressed a range of key issues in grammar instruction, particularly direct (explicit) or indirect (integrated) grammar instruction. The participants were asked to mark the most suitable response for each item on a five-point Likert scale (strongly disagree, disagree, unsure, agree, and strongly agree). The current study uses this questionnaire as the only data collection tool and this is mainly how it differs from that of Burg and Burns (2008), whose additional aim was to elicit teachers' conceptualizations of what integration is by asking a set of open-ended questions.

\subsection{Exploratory Factor Analysis (EFA): Direct (Explicit) and Indirect (Integrated) Grammar Instruction}

The questionnaire devised by Burg and Burns (2008) consisted 15 items, some of which focused on direct (explicit) grammar teaching and others on indirect (integrated) teaching of grammar. In order to account for the type of grammar instruction each item addresses, exploratory factor analysis (EFA) was conducted. The motivation behind conducting the factor analysis is not to work on the mean or total scores of the questionnaire as a whole, but rather to explain individual items in terms of direct or indirect grammar instruction. Prior to EFA, Kaiser-Meyer-Olkin (KMO) test was used to test factorization fit of the sample size. KMO value of the sample that consisted of 75 participants was found 0.56. Also, the result of Bartlett Sphericity Test was significant. These findings showed that the data set had good fit for factor analysis. In order to show factor-construct of the questionnaire, principal components analysis and Varimax were employed. 0.32 was taken as the minimum limit for factor loadings while deciding whether the scale items were to be extracted or not.

As a result of exploratory factor analysis, factors were determined through eigen values and scree plot graphs. It was seen that two factors had eigen values higher than 1, the split in scree plot was in the second factor, and a plateau pattern was seen on the graph followed by that value. Thus, a two-factor restriction was decided. As a 
result of EFA, the questionnaire was grouped under two factors and the rotated factor loadings are presented in Table 5.

Table 5. Exploratory Factor Analysis (EFA) results for the questionnaire

\begin{tabular}{ll}
\hline Factor I: & Rotated Factor Loading \\
Direct (Explicit) Grammar Instruction &, 539 \\
\hline ITEM 1 &, 611 \\
ITEM 2 &, 755 \\
ITEM 3 &, 534 \\
ITEM 4 &, 598 \\
ITEM 6 &, 475 \\
ITEM 8 &, 648 \\
ITEM 9 &, 500 \\
ITEM 10 &, 460 \\
ITEM 11 &, 299 \\
ITEM 15 & \\
Eigen Value=3.72 and Explained Variance=20.97\% & Rotated Factor Loading \\
\hline Factor II: &, 651 \\
Indirect (Integrated) Grammar Instruction &, 610 \\
\hline ITEM 5 &, 539 \\
ITEM 7 &, 399 \\
ITEM 12 &, 625 \\
ITEM 13 & \\
ITEM 14 & \\
Eigen Value= 1.98 and Explained Variance= $14.10 \%$ & \\
KMO: .56 & \\
Total Explained Variance: $35.07 \%$ & \\
\hline
\end{tabular}

When the content of each individual item in the questionnaire was analyzed, supported by the results of the explanatory factor analysis, two factors were identified, namely "Direct (Explicit) Grammar Instruction" (factor I) and "Indirect (Integrated) Grammar Instruction" (factor II). As it is clear from Table 5, to begin with, the first factor consisted of 10 items and the vertically rotated factor loadings by using Varimax method ranged from 0.460 to 0.755 , except for item 15 . Only this item had a loading of 0.299 , whose content fit for the direct (explicit) grammar instruction factor; therefore, it was grouped under factor I. The unique variance explained by this factor was 20.97\%. Secondly, "Indirect (Integrated) Grammar Instruction", the second factor of the questionnaire, consisted of 5 items and the vertically rotated factor loadings by using Varimax method ranged from 0.399 to 0.651 . The unique variance explained by this factor was $14.10 \%$.

\subsection{Data Analysis}

Statistical analyses of the quantitative questionnaire responses were conducted using SPSS 21. In order to account for NNS teachers' beliefs about grammar instruction (the first research question), frequency counts of the participants' responses to the questionnaire items were first calculated. More to the point, frequency analyses of some individual questionnaire items produced notably higher scores towards both ends (strongly disagree and strongly agree) on the Likert scale; thus, they were independently presented and interpreted to support the findings. As a result, multiple bodies of statistical results are collectively presented in order to elucidate the beliefs held by NNS teachers about grammar instruction.

As for the second research question, nonparametric tests were used in order to compare subgroups within different demographic variables for each individual questionnaire item. Here, nonparametric tests (Mann-Whitney U test for two levels and Kruskal-Wallis $\mathrm{H}$ test for more than two) rather than parametric ones were employed. Assumption of normality was tested by Shapiro-Wilk test. The results of Shapiro-Wilk pointed 
out the necessity to use nonparametric analyses. For each demographic variable with more than 2 subgroups, Kruskal-Wallis H test was initially conducted. Only in "participants' qualification" and "participants' proficiency level" were there two groups; therefore, Mann-Whitney U test was applied to test the difference between subgroups for these two demographic variables.

\subsection{Results}

\subsubsection{Descriptive Results - Research Question 1}

The frequency counts of participants' responses for each individual item in the questionnaire have produced substantial results. Table 6 illustrates percentages and the number of participant responses for each item in the questionnaire. When presenting the results in this part, the percentages of "strongly disagree" and "disagree" as well as those of "strongly agree" and "agree" will be combined in order to attain more comprehensible justification of the responses. First, results of the direct items with high percentages at both ends will be reported. Later, indirect items with high frequency counts in both directions will be given. Next, results of items with relatively even distribution towards both ends will be accounted for. Finally, items with substantial frequency of "unsure" will be presented.

The majority of participant teachers state that they either agree or strongly agree in items 1, 2, 3, 8 and 15 (direct items). $58.7 \%$ of the participants believe teachers should present grammar to learners before expecting them to use it (item 1). On the other hand, only $26.6 \%$ of participants either disagree or strongly disagree with the item, indicating that few participants prefer students' own discovery of grammar rules integrated with other skills (inductive teaching) during language instruction. Similarly, $61.3 \%$ of teachers believe that learners who are aware of grammar rules can use the language more effectively than those who are not (item 2). Moreover, $77.3 \%$ of teachers believe that exercises which get learners to practice grammar structures help learners develop fluency in using grammar (item 3 ). As for the $8^{\text {th }}$ item, $65.4 \%$ of the participants think repeated grammar practice allows learners to use structures fluently. Correspondingly, in the $15^{\text {th }}$ item, $60 \%$ of participants point out to the necessity to study the grammar of a target language in order to speak it fluently.

Here, item 6 (direct) requires special attention. $81.3 \%$ of the participants either disagree or strongly disagree that grammar should be taught separately, not integrated with other skills such as reading and writing. While the sample hold strong views about the explicit (direct) teaching of grammar, they still show strong disagreement in its separation from other skills.

As for the indirect items in the questionnaire, the participants responses have revealed that the majority of the participants either agree or strongly agree in items 5, 7, 12, 13, and 14 (indirect items). 57.4\% of the sample believe that a focus on grammar in lessons should come after communicative tasks, not before (item 5). Nonetheless, there is still $25.3 \%$ who think the opposite. Next, $77.4 \%$ of the teachers maintain that grammar is not taught directly in a communicative approach to language teaching (item 7). Similarly, $60 \%$ of the participant teachers see grammar learning to be more effective when learners work out the rules for themselves (item 12). Moreover, the results of the next item (item 13) correspond with these findings, where $62.7 \%$ of the teachers think indirect grammar teaching is more appropriate with younger than with older learners. As the last point in this part, the results show that $54.7 \%$ of the participants believe formal grammar teaching does not help learners become more fluent (item 14).

A number items have produced considerable percentages in the "unsure" column. Of all the participants of the study, 21.3\% in item 4 (direct), 20\% in item 12 (indirect), and 24\% in item 14 (indirect) have marked the "unsure" option. Although only these 3 items have produced more than $20 \%$ of unsure results, the percentage is not low considering the communicative content of the teacher training course that the participants completed.

Table 6. Frequency counts of participants' responses to questionnaire items

\begin{tabular}{|c|c|c|c|c|c|c|}
\hline \multirow{2}{*}{\multicolumn{2}{|c|}{ Questionnaire Items }} & \multicolumn{5}{|c|}{ Percentages (n) } \\
\hline & & \multirow{2}{*}{$\begin{array}{l}\begin{array}{l}\text { Strongly } \\
\text { disagree }\end{array} \\
5,3(4)\end{array}$} & \multirow{2}{*}{$\begin{array}{l}\text { Disagree } \\
21,3(16)\end{array}$} & \multirow{2}{*}{$\begin{array}{l}\text { Unsure } \\
14,7(11)\end{array}$} & \multirow{2}{*}{$\begin{array}{l}\text { Agree } \\
45,3(34)\end{array}$} & \multirow{2}{*}{$\begin{array}{l}\begin{array}{l}\text { Strongly } \\
\text { agree }\end{array} \\
13,3(10)\end{array}$} \\
\hline 1. & $\begin{array}{l}\text { Teachers should present grammar to } \\
\text { learners before expecting them to use it. }\end{array}$ & & & & & \\
\hline 2. & $\begin{array}{l}\text { Learners who are aware of grammar rules } \\
\text { can use the language more effectively than } \\
\text { those who are not. }\end{array}$ & $5,3(4)$ & $17,3(13)$ & $16(12)$ & $45,3(34)$ & $16(12)$ \\
\hline
\end{tabular}




\begin{tabular}{|c|c|c|c|c|c|c|}
\hline \multirow{2}{*}{\multicolumn{2}{|c|}{ Questionnaire Items }} & \multicolumn{5}{|c|}{ Percentages (n) } \\
\hline & & \multirow{2}{*}{$\begin{array}{l}\begin{array}{l}\text { Strongly } \\
\text { disagree }\end{array} \\
2,7(2)\end{array}$} & \multirow{2}{*}{$\begin{array}{l}\text { Disagree } \\
8(6)\end{array}$} & \multirow{2}{*}{$\begin{array}{l}\text { Unsure } \\
12(9)\end{array}$} & \multirow{2}{*}{$\begin{array}{l}\text { Agree } \\
49,3(37)\end{array}$} & \multirow{2}{*}{$\begin{array}{l}\begin{array}{l}\text { Strongly } \\
\text { agree }\end{array} \\
28(21)\end{array}$} \\
\hline 3. & $\begin{array}{l}\text { Exercises that get learners to practice } \\
\text { grammar structures help learners develop } \\
\text { fluency in using grammar. }\end{array}$ & & & & & \\
\hline 4. & $\begin{array}{l}\text { Teaching the rules of English grammar } \\
\text { directly is more appropriate for older } \\
\text { learners. }\end{array}$ & $12(9)$ & $20(15)$ & $21,3(16)$ & $34,7(26)$ & $12(9)$ \\
\hline 5. & $\begin{array}{l}\text { During lessons, a focus on grammar should } \\
\text { come after communicative tasks, not } \\
\text { before. }\end{array}$ & $5,3(4)$ & $20(15)$ & $17,3(13)$ & $45,3(34)$ & $12(9)$ \\
\hline 6. & $\begin{array}{l}\text { Grammar should be taught separately, not } \\
\text { integrated with other skills such as reading } \\
\text { and writing. }\end{array}$ & $26,7(20)$ & $54,7(41)$ & $2,7(2)$ & $12(9)$ & $4(3)$ \\
\hline 7. & $\begin{array}{l}\text { In a communicative approach to language } \\
\text { teaching grammar is not taught directly. }\end{array}$ & $1,3(1)$ & $8(6)$ & $13,3(10)$ & $60(45)$ & $17,3(13)$ \\
\hline 8. & $\begin{array}{l}\text { In learning grammar, repeated practice } \\
\text { allows learners to use structures fluently. }\end{array}$ & $1,3(1)$ & $16(12)$ & $17,3(13)$ & $53,3(40)$ & $12(9)$ \\
\hline 9. & $\begin{array}{l}\text { In teaching grammar, a teacher's main role } \\
\text { is to explain the rules. }\end{array}$ & $16(12)$ & $28(21)$ & $13,3(10)$ & $42,7(32)$ & 0 \\
\hline & $\begin{array}{l}\text { It is important for learners to know } \\
\text { grammatical terminology. }\end{array}$ & $10,7(8)$ & $26,7(20)$ & $14,7(11)$ & $37,3(28)$ & $10,7(8)$ \\
\hline 11. & $\begin{array}{l}\text { Correcting learners' spoken grammatical } \\
\text { errors in English is one of the teacher's key } \\
\text { roles. }\end{array}$ & $8(6)$ & $33,3(25)$ & $13,3(10)$ & $37,3(28)$ & $8(6)$ \\
\hline 12. & $\begin{array}{l}\text { Grammar learning is more effective when } \\
\text { learners work out the rules for themselves. }\end{array}$ & $2,7(2)$ & $17,3(13)$ & $20(15)$ & $41,3(31)$ & $18,7(14)$ \\
\hline & $\begin{array}{l}\text { Indirect grammar teaching is more } \\
\text { appropriate with younger than with older } \\
\text { learners. }\end{array}$ & $6,7(5)$ & $13,3(10)$ & $17,3(13)$ & $44(33)$ & $18,7(14)$ \\
\hline & $\begin{array}{l}\text { Formal grammar teaching does not help } \\
\text { learners become more fluent. }\end{array}$ & $4(3)$ & $17,3(13)$ & $24(18)$ & $46,7(35)$ & $8(6)$ \\
\hline & $\begin{array}{l}\text { It is necessary to study the grammar of a } \\
\text { second or foreign language in order to } \\
\text { speak it fluently. }\end{array}$ & $5,3(4)$ & $18,7(14)$ & $16(12)$ & $49,3(37)$ & $10,7(8)$ \\
\hline
\end{tabular}

\subsubsection{Predictive Results - Research Question 2}

In order to account for the second research question, responses given to each individual questionnaire item were analyzed according to subgroups of the demographic variables. The analyses have produced some significant results between/among subgroups of participants regarding their qualification, their students' age, proficiency level of their students, and their English proficiency level. The predictive results in this part will be presented in this corresponding order.

\subsubsection{Participants' Qualifications}

In terms of participants' qualifications, a significant difference between two subgroups (teachers with only BA degrees and teachers with MA or PhD degrees) has been found in item 6 and item 11.

Table 7 presents the significance values of items for this demographic variable. Mean rank of teachers with BA is lower than that of teachers with MA or PhD in item 6 (direct). So, the higher the participants' qualification, the more they have a tendency to teach grammar integrated with other skills. Similar results of item 11 (direct) show that mean rank of teachers with $\mathrm{BA}$ is lower than that of teachers with $\mathrm{MA}$ or $\mathrm{PhD}$. So, the higher the participants' qualification, the less they have a tendency to correct spoken grammatical errors. Table 8 shows detailed results of Mann-Whitney U test for items 6 and 11 according to teachers' qualifications. 
Table 7. Item significance (p) values according to participants' qualifications (Mann-Whitney U)

\begin{tabular}{llllllllllllllll}
\hline Items & 1 & 2 & 3 & 4 & 5 & 6 & 7 & 8 & 9 & 10 & 11 & 12 & 13 & 14 & 15 \\
\hline $\mathrm{P}$ & .762 & .429 & .801 & .248 & .862 & .001 & .200 & .311 & .294 & .483 & .042 & .306 & .546 & .306 & .520 \\
\hline
\end{tabular}

Table 8. Mann-whitney U Test results according to participants' qualifications (Items 6 and 11)

\begin{tabular}{llllllll}
\hline Items & Participant Groups & $\mathrm{N}$ & $\begin{array}{l}\text { Mean } \\
\text { Rank }\end{array}$ & $\begin{array}{l}\text { Sum } \\
\text { Ranks }\end{array}$ & of & $\mathrm{p}$ \\
\hline Item 6 & $\mathrm{BA}$ & 39 & 45.42 & 1771.50 & 412.500 & .001 \\
& $\mathrm{MA} / \mathrm{PhD}$ & 36 & 29.96 & 1078.50 & & \\
Item 11 & $\mathrm{BA}$ & 39 & 42.69 & 1665 & 519.000 & .042 \\
& $\mathrm{MA} / \mathrm{PhD}$ & 36 & 32.92 & 1185 & & \\
\hline
\end{tabular}

\subsubsection{Ages of Participants' Students}

Analyses have revealed significant differences between subgroups of teachers according to their students' ages in items 3, 11 and 12. Table 9 presents the significance values of the questionnaire items for this demographic variable. As the detailed results of the Kruskal-Wallis $\mathrm{H}$ test indicate in Table 10, mean rank of responses given by teachers who teach English to students aged 24 and above (graduate/in-service) is higher than that of high school English teachers in items 3 and 11 (both direct items). In other words, the higher the ages of participants' students, the more they have a tendency to believe that grammar exercises help learners develop fluency in using grammar. What is more, when compared to teachers who teach high school students, teachers who teach adult learners have a higher tendency to correct learners' spoken grammatical errors in English. As for the item 12 (indirect), mean rank of responses by teachers who teach university/academy students is higher than that of teachers of adult learners. This finding corresponds with the previous results in that the lower the ages of their students, the more the participants believe that grammar learning is more effective when learners work out the rules for themselves. This shows the tendency of teachers of relatively younger students to teach grammar indirectly.

Table 10. Item significance (p) values according to participants' students' ages (Kruskal-Wallis H)

\begin{tabular}{llllllllllllllll}
\hline Items & 1 & 2 & 3 & 4 & 5 & 6 & 7 & 8 & 9 & 10 & 11 & 12 & 13 & 14 & 15 \\
\hline $\mathrm{P}$ & .267 & .611 & .017 & .681 & .280 & .729 & .847 & .191 & .196 & .437 & .035 & .021 & .359 & .099 & .394 \\
\hline
\end{tabular}

Table 11. Kruskal-wallis h test results according to participants' students' ages (Items 3, 11 and 12)

\begin{tabular}{lllllll}
\hline Items & Participant Groups & $\mathrm{N}$ & Mean Rank & Sum of Ranks & $\mathrm{U}$ & $\mathrm{p}$ \\
\hline Item 3 & High School Sts (Ages 15-18) & 8 & 14.06 & 112.50 & 76.500 & .003 \\
& Graduate / In-service Sts (24 and above) & 48 & 30.91 & 1483.50 & & \\
Item 11 & High School Sts (Ages 15-18) & 8 & 16.06 & 128.50 & 92.500 & .015 \\
& Graduate / In-service Sts (24 and above) & 48 & 30.57 & 1467.50 & & \\
\multirow{2}{*}{ Item 12 } & University / Academy Sts (Ages 19-23) & 19 & 43.74 & 831 & 271.000 & .007 \\
& Graduate / In-service Sts (24 and above) & 48 & 30.15 & 1447 & & \\
\hline
\end{tabular}

\subsubsection{Proficiency Level of Participants' Students}

According to the results, there is a significant difference between subgroups of teachers according to proficiency level of their students in item 15 (direct). Table 11 illustrates the significance values of the questionnaire items for this demographic variable. More specifically, mean rank of responses provided by teachers of advanced learners are higher than that of teachers of both elementary level learners and intermediate level learners. Thus, the higher the proficiency level of their students, the more the participants have a tendency to find it necessary to study the grammar in order to speak the target language fluently. In other words, participant teachers view grammar instruction to be more essential for their students as the students improve their proficiency in the target language (Table 12). 
Table 11. Item significance (p) values according to proficiency level of participants' sts (Kruskal-Wallis H)

\begin{tabular}{llllllllllllllll}
\hline Items & 1 & 2 & 3 & 4 & 5 & 6 & 7 & 8 & 9 & 10 & 11 & 12 & 13 & 14 & 15 \\
\hline $\mathrm{P}$ & .550 & .265 & .841 & .189 & .358 & .267 & .248 & .650 & .782 & .052 & .713 & .331 & .869 & .211 & .041 \\
\hline
\end{tabular}

Table 12. Kruskal-wallis h test results according to proficiency level of participants' students (Item 15)

\begin{tabular}{lllllll}
\hline Items & Participant Groups & $\mathrm{N}$ & Mean Rank & Sum of Ranks & $\mathrm{U}$ & $\mathrm{p}$ \\
\hline Item 15 & Elementary & 33 & 24.17 & 797.50 & 236.500 & .037 \\
& Advanced & 21 & 32.74 & 687.50 & & \\
& Intermediate & 21 & 17.52 & 368 & 137.000 & .026 \\
& Advanced & 21 & 25.48 & 535 & & \\
\hline
\end{tabular}

\subsubsection{Participants' Proficiency in English}

Finally, results have revealed significant differences between subgroups of teachers according to their English proficiency in direct items $6,7,11$ and 12 . The significance values of the questionnaire items for this demographic variable are given in Table 13 and the detailed results of the Mann-Whitney U in Table 14. As the tables show, mean rank of Group 1 (CAT ECL: 80-90) is higher than that of Group 2 (CAT ECL: 91-100) in item 6 (direct item). In other words, the higher the proficiency level of participants, the more they have a tendency to teach grammar integrated with other skills, not separately. This finding also corresponds with the results of the earlier demographic variable, where teachers with MA and $\mathrm{PhD}$ degrees showed similar tendency. What is more, in item 7 (indirect), mean rank of Group 1 (CAT ECL: 80-90) is lower than that of Group 2 (CAT ECL: 91-100). This finding reveals that the higher the proficiency level of teachers, the more they believe that grammar should be taught indirectly in a communicative approach setting. Next, in item 11 (direct), mean rank of Group 1 (CAT ECL: 80-90) is higher than that of Group 2 (CAT ECL: 91-100). This indicates that teachers with higher proficiency level tend not to see correcting spoken grammatical errors as one of the teacher's key roles. This finding is significant since the participants' scores of the 5-likert scale in this item is equally distributed towards both ends. Lastly, in item 14 (indirect), mean rank of Group 1 (CAT ECL: 80-90) is lower than that of Group 2 (CAT ECL: 91-100). Thus, teachers with higher proficiency level think that formal grammar teaching does not improve learners' fluency. In other words, the higher the proficiency level of participants, the more they tend to avoid formal (direct) grammar instruction.

Table 13. Item significance (p) values according to participants' English proficiency (Mann-Whitney U)

\begin{tabular}{llllllllllllllll}
\hline Items & 1 & 2 & 3 & 4 & 5 & 6 & 7 & 8 & 9 & 10 & 11 & 12 & 13 & 14 & 15 \\
\hline $\mathrm{P}$ & .543 & .518 & .156 & .819 & .685 & .010 & .023 & .436 & .161 & .100 & .024 & .116 & .408 & .021 & .802 \\
\hline
\end{tabular}

Table 14. Mann-whitney u test results according to participants' English proficiency (Items 6, 7, 11, 14)

\begin{tabular}{lllllll}
\hline Items & Participant Groups & $\mathrm{N}$ & Mean Rank & Sum of Ranks & $\mathrm{U}$ & $\mathrm{p}$ \\
\hline Item 6 & CAT ECL Score: $80-90$ & 20 & 47.73 & 954.50 & 355.500 & .010 \\
& CAT ECL Score: $91-100$ & 55 & 34.46 & 1895.50 & & \\
\multirow{2}{*}{ Item 7 } & CAT ECL Score: $80-90$ & 20 & 29.65 & 593 & 383.000 & .023 \\
& CAT ECL: Score $91-100$ & 55 & 41.04 & 2257 & & \\
Item 11 & CAT ECL Score: $80-90$ & 20 & 46.95 & 939 & 371.000 & .024 \\
& CAT ECL Score: $91-100$ & 55 & 34.75 & 1911 & & \\
Item 14 & CAT ECL Score: $80-90$ & 20 & 28.95 & 579 & 369.000 & .021 \\
& CAT ECL Score: $91-100$ & 55 & 41.29 & 2271 & & \\
\hline
\end{tabular}

\section{Discussion}

The discussion of the results will be presented focusing on the two research questions. First, the descriptive results obtained from frequency counts of responses given to the questionnaire items will be discussed. Later, 
informed by the predictive results, comments will be provided as to how the beliefs of participant teachers are influenced by different demographic variables.

Generally, this study provides supportive evidence to current research which suggests that EFL teachers favor some elements of direct grammar teaching (Schulz, 1996; Eisenstein-Ebsworth \& Schweers, 1997). The participants here indicated that they favored deductive grammar teaching, where rules are presented explicitly prior to student production and pointed towards the necessity to know grammar rules explicitly on the part of the students for effective use of target language. They also supported explicit grammar exercises in their teaching, which can also be categorized under direct grammar instruction. They also thought repeated grammar practice allowed learners to use structures fluently, which shows their preference of direct grammar instruction through repetitive grammar drills.

While the sample held strong views about the explicit (direct) teaching of grammar, they still showed strong opposition to its separation from other skills. In other words, although participants preferred direct and explicit grammar teaching to a certain extent, they opposed to its total isolation in their instruction. Moreover, they preferred communication-based activities before a particular emphasis on grammatical rules in lessons. This is noteworthy since it shows that although participants favored explicit presentation of grammar rules before expecting the students to use them, they still thought that explicit grammar instruction should come after communicative tasks in the lesson. Taking into consideration the strong views of the sample favoring direct grammar teaching, this finding shows that they associate indirect grammar instruction with the term "communicative approach". In other words, when communication is emphasized in language teaching, grammar is perceived by the sample as something to be taught indirectly or integrated with other communicative tasks. Furthermore, teachers thought indirect grammar teaching was more appropriate with younger learners than with adult learners. Apparently, they associated indirect grammar instruction with younger students, who enjoy songs, games and other integrated activities more than formal grammar teaching.

The representation of grammar instruction that arises from participant teachers' responses to the 15 -item questionnaire in this study is one characterized by systematic explicit grammar teaching with regular opportunities for grammar practice, not in isolation but in relation to skills-oriented work. Teachers also showed their tendency to encourage students to discover rules themselves without ignoring the necessity to use direct grammar instruction. With these perspectives, the current study adds to the literature with similar findings about teachers' perceptions on grammar instruction (Andrews, 2003; Schulz, 2001; Borg \& Burns, 2008). Interestingly, besides teachers' strong beliefs about the necessity of using direct grammar instruction, there was still some degree of uncertainty among participants on the role of direct and indirect grammar instruction. Some participants showed doubts about the nature of grammar teaching in foregin language education, which might result from discrepancy between the theory and their actual in-class experiences.

The reported beliefs of teachers significantly related to some particular demographic variables and the corresponding subgroups of participants. The comments here can be grouped under two topics of discussion. First of all, teachers with higher English proficiency levels and higher degrees (MA/PhD) showed stronger belief towards teaching grammar indirectly. In other words, teachers who held only BA degrees and had lower proficiency in English favored to teach grammar more explicitly. Also, teachers with $\mathrm{MA}$ and $\mathrm{PhD}$ degrees tended to avoid the isolation of grammar instruction from other skills. Moreover, the belief held by teachers with $\mathrm{MA}$ and $\mathrm{PhD}$ that spoken accuracy could be neglected in favor of fluency indicated that teachers with higher degrees preferred to attach less significance to grammatical correctness especially in oral production.

Another significant insight emerged from the study was that teachers of adult learners, especially those who taught learners at 24 years of age and above, showed a higher tendency towards direct grammar teaching. Teachers of learners with respectively higher ages thought grammar exercises helped learners develop fluency in using grammar. They also showed a stronger tendency to correct learners' spoken grammatical errors in English. However, teachers of younger learners tended to disagree with the idea that this was a vital role that they needed to fulfill. This same belief was also held by teachers with higher English proficiency levels. Correspondingly, teachers of relatively younger students reported that grammar learning was more effective when learners worked out the rules for themselves in an indirect manner. Additionally, the proficiency level of students that the participants taught also had an impact on their preferences in terms of grammar instruction. Interestingly, teachers of higher advanced level students found it more necessary to study the grammar in order to speak the target language fluently. They viewed grammar instruction to be more essential for their students as the students advanced in the language. These tendencies may be summarized here that the participants tended to use more indirect grammar instruction as they progressed academically and proficiency-wise, but they implemented more direct grammar teaching as the ages and level of their students increased. 
In order to draw more comprehensive conclusions on the beliefs and practices of non-native English teachers, further research is necessary. It should be acknowledged that the current study does not include actual teaching practices of the participants; thus, the conclusions are based on teachers' stated beliefs and their reported classroom practices. Future research might involve classroom observations of non-native speaker teachers while teaching grammar components. What is more, the geographically diverse nature of the sample can also be taken as a limitation, which does not allow to extend the conclusions beyond the group of non-native teachers studied here. The study might be duplicated with a larger sample size or with non-native speaker teachers of a single country.

Consequently, with the above-mentioned limitations in mind, this research has provided a number of valuable insights, particularly in relation to teachers' beliefs about grammar instruction. It may be argued that the traditional structural methodology still predominates in language classrooms although the communicative approach and an associated task-based methodology is promoted both in literature and conferences alike. In other words, teachers are doing one thing while being urged to do something else. Today, most ELT theorists support the communicative approach in principle and recommend implementing this in task-based instruction (Ogilvie \& Dunn, 2010), yet it seems that there is also a room for explicit grammar instruction in the classrooms especially based on the reported beliefs of non-native language teachers. Then, what should the nature of that explicit grammar instruction be? How can direct grammar teaching be achieved in the most meaningful and contextual way? Those questions can be most productively answered by the collaborative efforts of teachers and researchers through a lens that takes into consideration what theory might suggest and what really happens in language classrooms.

\section{References}

Anastasi, A. (1982). Psychological testing. London: Macmillan.

Andrews, S. (2003). "Just like instant noodles": L2 teachers and their beliefs about grammar pedagogy, Teachers and Teaching: Theory and Practice, 9(4), 351-75. https://doi.org/10.1080/1354060032000097253

Andrews, S. (2007). Teacher language awareness. Cambridge: Cambridge University Press. https://doi.org/10.1017/CBO9780511497643

Bailey, K. M. (1996). The best laid plans: teachers' in-class decisions to depart from their lesson plans. In K. M. Bailey, \& D. Nunan (Eds): Voices from the Language Classroom. Cambridge: Cambridge University Press.

Basturkmen, H., Loewen, S., \& Ellis, R. (2004). Teachers' stated beliefs about incidental focus on form and their classroom practices. Applied Linguistics, 25, 243-272. https://doi.org/10.1093/applin/25.2.243

Borg, S. (1998a). Talking about grammar in the foreign language classroom. Language Awareness, 7(4), 159-175. https://doi.org/10.1080/09658419808667107

Borg, S. (1998b). Teachers' pedagogical systems and grammar teaching: A qualitative study. TESOL Quarterly, 32(1), 93-8. https://doi.org/10.2307/3587900

Borg, S. (1999). The use of grammatical terminology in the second language classroom: A qualitative study of teachers' practices and cognitions. Applied Linguistics, 20(1), 95-126. https://doi.org/10.1093/applin/20.1.95

Borg, S. (2001). Self-perception and practice in teaching grammar. ELT Journal, 55(1), 21-29. https://doi.org/10.1093/eltj/55.1.21

Borg, S. (2003a). Teacher cognition in language teaching: A review of research on what language teachers think, know, believe, and do. Language Teaching, 36(2), 81-109. https://doi.org/10.1017/S0261444803001903

Borg, S. (2003b). Teacher cognition in grammar teaching: A literature review. Language Awareness, 12(2), 96-108. https://doi.org/10.1080/09658410308667069

Borg, S. (2005). "Experience, knowledge about language and classroom practice in teaching grammar." In N. Bartels (Ed.), Researching applied linguistics in language teacher education (pp. 325-340). New York: Springer. https://doi.org/10.1007/1-4020-2954-3_19

Borg, S. (2006). Teacher cognition and language education: Research and practice. London: Continuum.

Borg, S., \& Burns, A. (2008). Integrating grammar in adult TESOL classrooms. Applied Linguistics, 29(3), 456-482. https://doi.org/10.1093/applin/amn020

Braine, G. (1999). Non-native educators in English language teaching. Mahwah, N.J.: L. Erlbaum. 
Brown, H. D. (2000). Principles of language learning and teaching. New York: Longman.

Brown, H. D. (2007). Teaching by principles: An interactive approach to language pedagogy (3rd Ed.). White Plains, NY: Pearson Education.

Burgess, J., \& Etherington, S. (2002). Focus on grammatical form: Explicit or implicit? System, 30, 433-458. https://doi.org/10.1016/S0346-251X(02)00048-9

Burns, A. (1996). Starting all over again: From teaching adults to teaching beginners. In D. Freeman, \& J. C. Richards (Eds): Teacher Learning in Language Teaching. Cambridge: Cambridge University Press.

Clark, E., \& Paran, A. (2007). The employability of non-native-speaker teachers of EFL: A UK survey. System, 35(4), 407-430. https://doi.org/10.1016/j.system.2007.05.002

Eisenstein-Ebsworth, M. \& Schweers, C. W. (1997). What researchers say and practitioners do: Perspectives on conscious grammar instruction in the ESL classroom. Applied Language Learning, 8(2), 237-60.

Ellis, R. (2006). Current issues in the teaching of grammar: An SLA perspective. TESOL Quarterly, 40, 83-107. https://doi.org/10.2307/40264512

Farrell, T. S. C., \& Lim, P. C. P. (2005). Conceptions of grammar teaching: A case study of teachers' beliefs and classroom practices. TESL-EJ, 9(2), 1-13.

Freeman, D. (2002). The hidden side of the work: Teacher knowledge and learning to teach. Language Teaching, 35(1), 1-13. https://doi.org/10.1017/S0261444801001720

Freeman, D., \& Richards, J. C. (Eds.). (1996). Teacher learning in language teaching. Cambridge: Cambridge University Press.

Gan, Z. (2013). Learning to teach English language in the practicum: What challenges do non-native ESL student teachers face? Australian Journal of Teacher Education, 38(3), 92-108. https://doi.org/10.14221/ajte.2013v38n3.3

Grubbs, F. E. (1969). Procedures for detecting outlying observations in samples. Technometrics, 11(1), 1-21. https://doi.org/10.1080/00401706.1969.10490657

Hayes, D. (2005). Exploring the lives of non-native speaking English educators in Sri Lanka. Teachers and Teaching, 11, 169-194. https://doi.org/10.1080/13450600500083964

Hayes, D. (2009). Non-native English-speaking teachers, context and English language teaching. System, 37(1), 1-11. https://doi.org/10.1016/j.system.2008.06.001

Johnson, K. E. (1999). Understanding Language Teaching: Reasoning in Action. Boston, MA: Heinle \& Heinle. https://doi.org/10.1177/136216889900300301

Knudson, R. E. (1999). Student teachers' beliefs related to literacy instruction for nonnative English speakers. Psychological Reports, 84(1), 317-318. https://doi.org/10.2466/pr0.1999.84.1.317

Llurda, E. (2005). Non-native language teachers: Perceptions, challenges and contributions to the profession. New York: Springer. https://doi.org/10.1007/b106233

Mahboob, A. (2010). The NNEST Lens: Non-native English Speakers in TESOL. Newcastle, England: Cambridge Scholars Publishing

Mauranen, A. (2012). Exploring ELF: Academic English shaped by non-native speakers. Cambridge: Cambridge University Press.

Ogilvie, G., \& Dunn, W. (2010). Taking teacher education to task: Exploring the role of teacher education in promoting the utilization of task-based language teaching. Language Teaching Research, 14(2), 161-181. https://doi.org/10.1177/1362168809353875

Pahissa, I., \& Tragant, E. (2009). Grammar and the non-native secondary school teacher in Catalonia. Language Awareness, 18, 47-60. https://doi.org/10.1080/09658410802307931

Schulz, R. A. (1996). Focus on form in the foreign language classroom: Students' and teachers' views on error correction and the role of grammar. Foreign Language Annals, 29(3), 343-64. https://doi.org/10.1111/j.1944-9720.1996.tb01247.x

Schulz, R. A. (2001). Cultural differences in student and teacher perceptions concerning the role of grammar teaching and corrective feedback: USA-Colombia. Modern Language Journal, 85(2), 244-58. https://doi.org/10.1111/0026-7902.00107 
Young, T. J., \& Walsh, S. (2010). Which English? Whose English? An investigation of 'non-native' teachers' beliefs about target varieties. Language Culture and Curriculum, 23, 123-138. https://doi.org/10.1080/07908311003797627

Woods, D. (1996). Teacher cognition in language teaching. Cambridge: Cambridge University Press.

\section{Copyrights}

Copyright for this article is retained by the author(s), with first publication rights granted to the journal.

This is an open-access article distributed under the terms and conditions of the Creative Commons Attribution license (http://creativecommons.org/licenses/by/4.0/). 